\title{
Reticulocyte Corpuscular Hemoglobin Distribution Width
}

National Cancer Institute

\section{Source}

National Cancer Institute. Reticulocyte Corpuscular Hemoglobin Distribution Width. NCI

Thesaurus. Code C139069.

A measurement of the standard deviation of hemog lobin concentrations in reticulocytes,

calculated as the standard deviation of hemoglobin content divided by the mean

hemoglobin content. 